\title{
Episodic ataxia type 5
}

INSERM

\section{Source}

INSERM. (1999). Orphanet: an online rare disease and orphan drug data base. Episodic ataxia type 5. ORPHA:211067

Episodic ataxia type 5 (EA5) is an extremely rare form of Hereditary episodic ataxia (see this term) characterized by recurrent episodes of vertigo and ataxia lasting several hours. 